\title{
Curcumin inhibits human retinal pigment epithelial cell proliferation
}

\author{
YUN SUN and ZHI-PENG YOU \\ Department of Ophthalmology, The Second Affiliated Hospital of Nanchang University, \\ Nanchang, Jiangxi 330006, P.R. China
}

Received March 31, 2014; Accepted July 11, 2014

DOI: 10.3892/ijmm.2014.1861

\begin{abstract}
Proliferative vitreoretinopathy (PVR) is a common cause of intraoperative failure following retinal reattachment surgery and is mediated in part through the migration, de-differentiation and proliferation of retinal pigment epithelial (RPE) cells. Given the cytotoxic effects of curcumin on epithelial and endothelial cells, in this study, we assessed the effects of curcumin on human RPE (hRPE) cell proliferation. WST-1 analysis revealed that curcumin significantly inhibited primary hRPE cell proliferation in a dose- and time-dependent manner $(\mathrm{P}<0.001)$ with the greatest inhibition observed at the dose of $15 \mu \mathrm{g} / \mathrm{ml}$ curcumin. Flow cytometric analysis indicated that the cytotoxic effects of curcumin on hRPE cell proliferation were mediated by cell cycle arrest at the G0/G1 phase and the induction of apoptosis (both $\mathrm{P}<0.001$ ), which was confirmed by ultrastructural analysis using transmission electron microscopy. Furthermore, western blot analysis revealed that curcumin induced $\mathrm{p} 53$ and $\mathrm{p} 21^{\mathrm{WAF} 1 / \mathrm{CIP} 1}$ expression with a concomitant decrease in proliferating cell nuclear antigen protein levels $(\mathrm{P}<0.05)$. Curcumin effectively inhibited primary hRPE cell proliferation, which may be mediated by the p53 pathway. Further in vivo studies are required in order to fully explore the therapeutic potential of curcumin for PVR.
\end{abstract}

\section{Introduction}

Retinal pigment epithelial (RPE) cells are a highly specific cell monolayer localized between the choroid and retina that

Correspondence to: Dr Zhi-Peng You, Department of Ophthalmology, The Second Affiliated Hospital of Nanchang University, 1 Minde Road, Nanchang, Jiangxi 330006, P.R. China

E-mail: yzp74@sina.com

Abbreviations: ANOVA, analysis of variance; ECM, extracellular matrix; FBS, fetal bovine serum; OD, optical density; PCNA, proliferating cell nuclear antigen; PVR, proliferative vitreoretinopathy; RPE cells, retinal pigment epithelial cells; SD, standard deviation

Key words: curcumin, proliferative vitreoretinopathy, retinal pigment epithelial cell, p53, p21 ${ }^{\mathrm{WAF1} / \mathrm{CIP} 1}$, proliferating cell nuclear antigen transports nutrients from the choroid to photoreceptors, phagocytizes outer segments of the photoreceptor and maintains retinal adhesion and intraocular pressure balance through water and ion transport $(1,2)$. The migration, de-differentiation and proliferation of RPE cells play important roles in the pathogenesis of proliferative vitreoretinopathy (PVR) (3-7), a common cause of intraoperative failure following retinal reattachment surgery, occurring in 5-10\% of patients with rhegmatogenous retinal detachment (8). Specifically, the diffusion of RPE cells into the intravitreal cavity induces the formation of a retraction membrane on the retina, resulting in the vitreous retraction of fibrous tissues and retinal detachment (8-10). Currently, the only effective strategy for the treatment of hyperplastic fibrous tissues is surgical detachment; however, repeated surgeries may result in PVR (11).

The mechanisms underlying the migration and proliferation of RPE cells remain poorly understood; however, the role of growth factors and cytokines $(3-7,12)$ in addition to factor Xa and thrombin (13) has been reported. The hyperplastic fibrous tissues of PVR are mainly composed of cells, including RPE cells, Müller glia, fibroblasts and macrophages, as well as an extracellular matrix (ECM) composed of collagen I and fibronectin $(14,15)$. In addition, growth factor expression, including insulin-like growth factor-binding protein-6 (IGFBP-6) (16) and vascular endothelial growth factor A (VEGF-A) (17), has been observed in the vitreous of PVR patients. The inhibition of the migration and proliferation of these cells may be helpful in preventing the recurrence of retinal detachment $(18,19)$. Although controversial, some clinicians have used the intravitreal or systemic injection of steroids to inhibit cell proliferation with poor efficacy $(20,21)$. In addition, although the inhibition of RPE cell proliferation in vitro has been achieved using tranilast (22), genistein (23), ciprofloxacin (24), vitamin C (25), vitamin E (26), minoxidil (27), hypericin (28), cis-hydroxyproline (29), retinoic acid (25), cis-vitamin A acid, aclacinomycin A (30), daunorubicin (31) and N,N-dimethyl doxorubicin (32), many of these drugs have side effects, which significantly limit their wide application in clinical practice.

In recent years, studies have demonstrated that curcumin, derived from the rhizome of Curcuma longa, may inhibit the proliferation of endothelial and epithelial cells; however, few studies have assessed its effects on RPE cells $(33,34)$. Therefore, this study aimed to examine the hypothesis that 
curcumin inhibits RPE cell proliferation. In addition, the possible mechanisms underlying the effects of curcumin were analyzed by determining the expression of pro-apoptotic factors (e.g., $\mathrm{p} 53$ and $\mathrm{p} 21^{\mathrm{WAF} / \mathrm{CIPI}}$ ) and proliferating cell nuclear antigen (PCNA).

\section{Materials and methods}

In vitro culture of human RPE (hRPE) cells. Primary RPE cells were obtained from ScienCell Research Laboratories (Carlsbad, CA, USA) which characterized them by immunofluorescence staining of cytokeratin-18, -19 and fibronectin. Cells infected with HIV-1, HCV, mycoplasma, bacteria, yeast and fungi were excluded. The cells were maintained in Dulbecco's modified Eagle's medium (DMEM)/F12 (Invitrogen, Carlsbad, CA, USA) containing $10 \%$ fetal bovine serum (FBS), $100 \mathrm{U} / \mathrm{ml}$ penicillin and $100 \mathrm{mg} / \mathrm{ml}$ streptomycin (all from Invitrogen) at $37^{\circ} \mathrm{C}$ in a humidified environment with $5 \% \mathrm{CO}_{2}$. The cells were passaged at a ratio of $1: 2$ when they reached $80 \%$ confluence after 2-3 days in culture.

Cell proliferation assay. The WST-1 kit (Roche, Indianapolis, IN, USA) was used to detect RPE cell proliferation and viability following the manufacturer's instructions. Briefly, the hRPE cells at passage 5 who had achieved a satisfactory growth were used to prepare a single-cell suspension. The cells were seeded onto 96-well plates $(5,000$ cells/well in $100 \mu \mathrm{l})$ and incubated at $37^{\circ} \mathrm{C}$ with $5 \% \mathrm{CO}_{2}$. The cells were treated with $5,10,15$, $20 \mu \mathrm{g} / \mathrm{ml}$ curcumin (dissolved in DMSO; Sigma-Aldrich, St. Louis, MO, USA) or DMSO. After 24, 48 and $72 \mathrm{~h}, 10 \mu \mathrm{l}$ of WST-1 solution were added to each well, followed by incubation for 1-4 h. The optical density (OD) was measured at $450 \mathrm{~nm}$ to determine the optimal concentration of the curcumin-mediated inhibition of proliferation.

Detection of apoptosis. The Annexin V-FIT apoptosis detection kit I (BD Pharmingen, San Jose, CA, USA) was used to detect curcumin-induced apoptosis. In brief, the hRPE cells were treated with $15 \mu \mathrm{g} / \mathrm{ml}$ curcumin or DMSO (control) for $48 \mathrm{~h}$, digested with EDTA-free trypsin (Invitrogen) and then washed twice with phosphate-buffered saline (PBS). Approximately $1-5 \times 10^{5}$ cells were collected and re-suspended in $500 \mu \mathrm{l}$ of binding buffer, $2 \mu \mathrm{l}$ of Annexin V-FITC and $5 \mu \mathrm{l}$ of propidium iodide (PI), followed by incubation in the dark at room temperature for $5 \mathrm{~min}$. Flow cytometry (using a flow cytometer; Beckman Coulter, Brea, CA, USA) was performed at an excitation of $488 \mathrm{~nm}$ and an emission of $530 \mathrm{~nm}$ to detect the apoptotic cells. Cells positive for Annexin V-FITC, but negative for PI were considered apoptotic; those positive for both Annexin V-FITC and PI were considered necrotic.

Cell cycle analysis. The hRPE cells were treated with $15 \mu \mathrm{g} / \mathrm{ml}$ curcumin or DMSO (control) for $48 \mathrm{~h}$, digested with EDTA-free trypsin (Invitrogen), washed twice with PBS and harvested by centrifugation. Following fixation in $70 \%$ ethanol at $4^{\circ} \mathrm{C}$ overnight, the cells were washed with $5 \mathrm{ml}$ of PBS and incubated with $500 \mu \mathrm{l}$ of PBS containing $100 \mu \mathrm{g} / \mathrm{ml}$ PI (Sigma-Aldrich), $100 \mu \mathrm{g} / \mathrm{ml}$ RNase A (Sigma-Aldrich) and 0.2\% Triton X-100, followed by incubation at $4^{\circ} \mathrm{C}$ in the dark for $30 \mathrm{~min}$ and flow cytometry.
Transmission electron microscopy. Following treatment with $15 \mu \mathrm{g} / \mathrm{ml}$ curcumin for 24,48 and $72 \mathrm{~h}$, the hRPE cells were harvested and seeded onto coverslips, which were washed twice with PBS and fixed in $2.5 \%$ glutaraldehyde at room temperature for $1 \mathrm{~h}$ and then in $2 \%$ osmic acid. Following washing in $0.1 \mathrm{M}$ PBS followed by distilled water, the cells were dehydrated in a graded ethanol series. Following treatment with Poly(diallyl phthalate) (PDAP; Sigma-Aldrich) and in situ embedding, ultra-thin sections were obtained, which were stained with $2 \%$ uranyl acetate and lead citrate. These sections were observed under a transmission electron microscope (JEM-1230; Joel, Tokyo, Japan).

Western blot analysis. Following treatment with $15 \mu \mathrm{g} / \mathrm{ml}$ curcumin for 24, 48 and $72 \mathrm{~h}$, the hRPE cells were harvested and lysed in RIPA lysis buffer (50 mM Tris, pH 7.4; $150 \mathrm{mM}$ $\mathrm{NaCl} ; 1 \%$ Triton X-100; $1 \%$ sodium deoxycholate; $0.1 \%$ SDS; sodium orthovanadate; sodium fluoride; EDTA; leupeptin), and the protein concentration was determined using the BCA method. Proteins $(50 \mu \mathrm{g})$ were separated with $12 \%$ SDS-PAGE and transferred onto PVDF membranes (Millipore, Billerica, MA, USA), which were incubated in blocking buffer (TBS, $0.1 \%$ Tween-20, 2\% BSA) at room temperature for $1 \mathrm{~h}$. After the membranes were washed 3 times in TBS (5 min/wash), they were incubated with the following primary antibodies at room temperature for $1.5 \mathrm{~h}$ : mouse anti-human $\mathrm{p} 21^{\mathrm{WAF} / / \mathrm{CP} 1}$ monoclonal antibody, mouse anti-human p53 monoclonal antibody, mouse anti-human PCNA monoclonal antibody (all from Santa Cruz Biotechnology, Inc., Dallas, TX, USA) and glyceraldehyde 3-phosphate dehydrogenase (GAPDH) monoclonal antibody (Cell Signaling Technology, Danvers, MA, USA). After washing in TBS, the membranes were incubated with HRP-conjugated secondary antibodies (1:2,000; Santa Cruz Biotechnology, Inc.) at room temperature for $1 \mathrm{~h}$ followed by chemiluminescence detection with an ECL GST Western Blotting Detection kit (Santa Cruz Biotechnology, Inc.). Quantity One software (Bio-Rad Laboratories, Hercules, CA, USA) was used to determine the OD of the bands, and GAPDH served as an internal reference.

Statistical analysis. Continuous data are presented as the means \pm standard deviation (SD). Curcumin-induced hRPE inhibition by dose at a given time or among different time points at a given dose was compared by one-way analysis of variance (ANOVA) with pair-wise post-hoc tests using Bonferroni correction. The apoptotic rate, cell necrotic rate, cell cycle and protein expression between the control and curcumintreated groups were compared by an independent $t$-test. All data analyses were performed using SPSS statistical software (version 17.0; SPSS Inc., Chicago, IL, USA). A two-tailed P-value $<0.05$ indicated a statistically significant difference.

\section{Results}

Inhibitory effects of curcumin on hRPE cell proliferation in vitro. The curcumin-mediated inhibition of hRPE cell proliferation was assessed following treatment with different doses of curcumin after 24, 48 and $72 \mathrm{~h}$. A dose-dependent inhibition in $\mathrm{hRPE}$ cell proliferation was observed at each time point analyzed $(\mathrm{P}<0.001)$ (Table I). Moreover, the inhibitory effects 
Table I. The inhibitory effects of curcumin on the proliferation of cultured human retinal pigment epithelial (hRPE) cells.

\begin{tabular}{lccccc}
\hline & \multicolumn{5}{c}{ Curcumin concentration $(\mu \mathrm{g} / \mathrm{ml})$} \\
\cline { 2 - 5 } Time (h) & 5 & 10 & 15 & 20 & $\mathrm{P}^{-\mathrm{value}}$ \\
\hline 24 & $5.07 \pm 2.66$ & $11.53 \pm 2.58$ & $15.85 \pm 2.71^{\mathrm{c}}$ & $21.32 \pm 1.67^{\mathrm{c}, \mathrm{d}}$ \\
48 & $11.24 \pm 0.44^{\mathrm{e}}$ & $15.44 \pm 2.52$ & $21.41 \pm 2.55^{\mathrm{c}, \mathrm{d}}$ & $26.38 \pm 1.09^{\mathrm{c}, \mathrm{d}, \mathrm{e}}$ & $<0.001$ \\
72 & $18.85 \pm 1.60^{\mathrm{e}, \mathrm{f}}$ & $29.69 \pm 0.75^{\mathrm{c}, \mathrm{e}, \mathrm{f}}$ & $39.96 \pm 3.88^{\mathrm{c}-\mathrm{f}}$ & $40.10 \pm 2.11^{\mathrm{c}-\mathrm{f}}$ & $<0.001$ \\
P-value $^{\mathrm{b}}$ & $<0.001$ & $<0.001$ & $<0.001$ & $<0.001$ & $<0.001$ \\
\hline
\end{tabular}

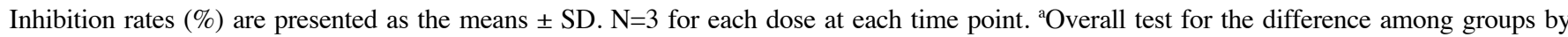
dose, determined by ANOVA. ' Overall test for the difference among groups over time, determined by ANOVA. Significantly different from the ${ }^{\mathrm{c}} 5,{ }^{\mathrm{d}} 10 \mu \mathrm{g} / \mathrm{ml}$ group, ${ }^{\mathrm{e}} 24$ and $^{\mathrm{f}} 48 \mathrm{~h}$ group as determined by Bonferroni correction, $\mathrm{P}<0.05$. SD, standard deviation; ANOVA, analysis of variance.

Table II. The effects of curcumin on the apoptosis and necrosis of cultured human retinal pigment epithelial (hRPE) cells after $48 \mathrm{~h}$.

\begin{tabular}{lcrr}
\hline & Control group & Curcumin-treated group & P-value $^{\mathrm{a}}$ \\
\hline Apoptotic rate $(\%)$, early phase & $7.03 \pm 0.37$ & $13.37 \pm 1.26$ & 0.001 \\
Apoptotic rate $(\%)$, mid-late phase & $0.09 \pm 0.00$ & $0.16 \pm 0.09$ & 0.307 \\
Apoptotic rate $(\%)$, total & $7.12 \pm 0.37$ & $13.53 \pm 1.18$ & 0.001 \\
Cell necrosis rate $(\%)$ & $4.40 \pm 0.18$ & $5.19 \pm 0.75$ & 0.154 \\
\hline
\end{tabular}

Data are presented as the means $\pm \mathrm{SD} ; \mathrm{N}=3$ for each group. ${ }^{\mathrm{a}}$ Determined by independent $\mathrm{t}$-test. $\mathrm{SD}$, standard deviation.
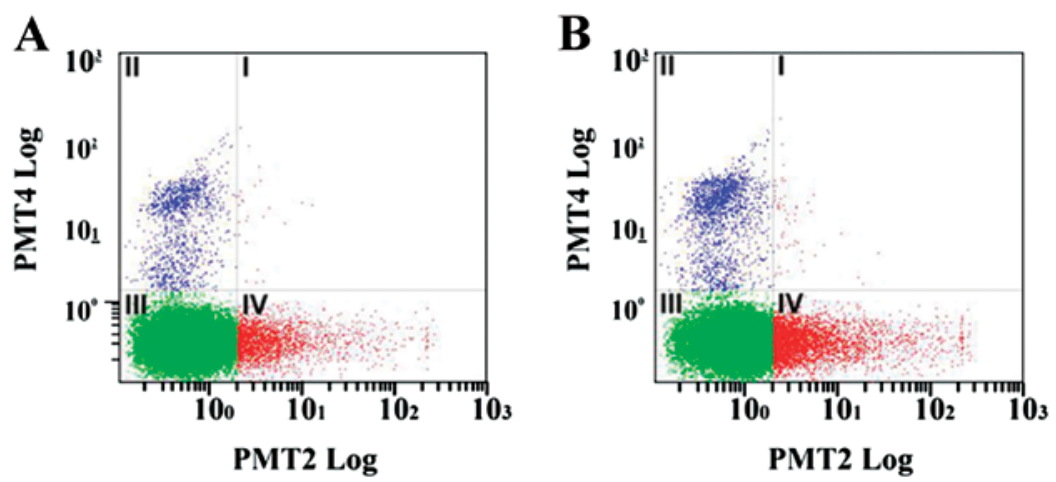

Figure 1. Effect of curcumin on the apoptosis and necrosis of human retinal pigment epithelial (hRPE) cells. Apoptotic and necrotic rates in (A) control and (B) curcumin-treated hRPE cells (15 $\mu \mathrm{g} / \mathrm{ml}$ curcumin for $48 \mathrm{~h}$ ). First quadrant, propidium iodide (PI) staining (necrotic cells); second quadrant, PI and Annexin V-FITC double staining (middle to late phase of apoptosis); forth quadrant: Annexin V-FITC staining (early phase of apoptosis).

of curcumin significantly increased with the increase in the treatment duration at each curcumin concentration $(\mathrm{P}<0.001)$. For both the 48- and 72-h time points, the proliferation inhibition rate of the cells treated with $15 \mu \mathrm{g} / \mathrm{ml}$ curcumin was significantly higher than that of the cells treated with 5 and $10 \mu \mathrm{g} / \mathrm{ml}$ curcumin at the same time points (all $\mathrm{P}<0.05$ ). The proliferation inhibition rate of the cells treated with $20 \mu \mathrm{g} / \mathrm{ml}$ curcumin was significantly higher than that of the cells treated with 5 and $10 \mu \mathrm{g} / \mathrm{ml}$ curcumin at all 3 time points; however, it did not differ significantly from that of the cells treated with $15 \mu \mathrm{g} / \mathrm{ml}$ curcumin (Table I). Therefore, the dose of $15 \mu \mathrm{g} / \mathrm{ml}$ curcumin was selected for the subsequent experiments.

Effects of curcumin on hRPE cell apoptosis and necrosis. The hRPE cells were treated with $15 \mu \mathrm{g} / \mathrm{ml}$ curcumin for
$48 \mathrm{~h}$ after which the proportion of apoptotic and necrotic cells was determined; representative data are shown in Fig. 1. As shown in Table II, the curcumin-treated group had a significantly greater proportion of cells in the early apoptotic phase (13.37 vs. $7.03 \% ; \mathrm{P}=0.001)$, resulting in a significantly higher overall apoptotic rate $(\mathrm{P}=0.001)$ compared to the control group. However, no significant difference was observed in the proportion of necrotic cells between the 2 groups (Table II).

A subsequent analysis of the effects of curcumin on the hRPE cell ultrastructure after $48 \mathrm{~h}$ was undertaken using transmission electron microscopy (Fig. 2). While the absence of apoptosis-induced changes in the cellular ultrastructure was noted in the normal control cells (Fig. 2A), changes associated with the different phases of apoptosis were observed in the curcumin-treated cells (Fig. 2B-H). Specifically, in early 

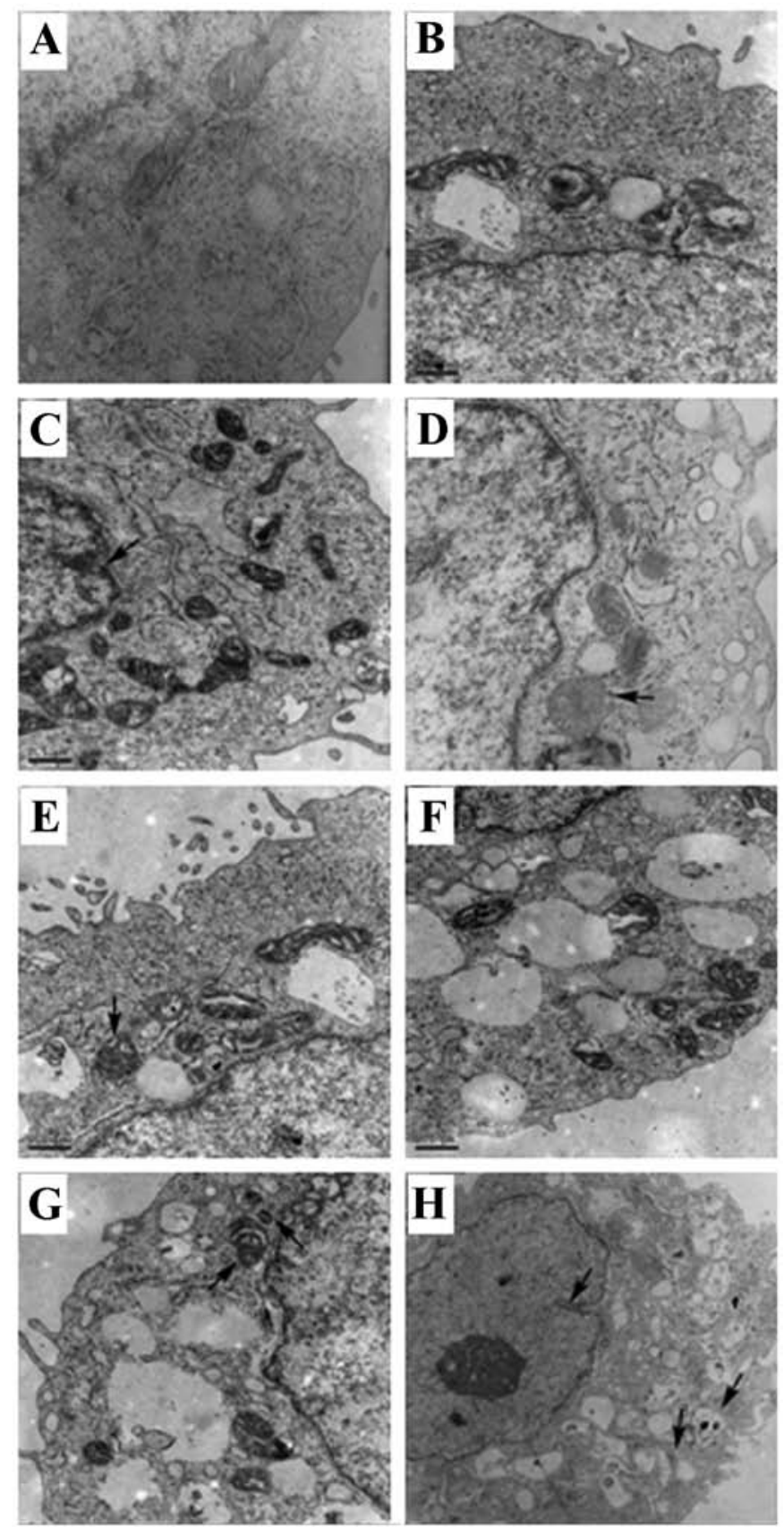

Figure 2. Ultrastructural analysis of human retinal pigment epithelial (hRPE) cells following treatment with curcumin. (A) hRPE cells in the normal control group (TEM x20,000; scale bar, $0.5 \mu \mathrm{m}$ ). (B and C) hRPE cells in the early phase of apoptosis (TEM x20,000; scale bar, $0.5 \mu \mathrm{m}$ ). The arrow in panel C indicates chromatin margination. (D-G) hRPE cells in the middle-to-late phase of apoptosis (TEM x20,000; scale bar, $0.5 \mu \mathrm{m}$ ). The arrows in panels D and E indicate mitochondrial swelling. The arrow on the left side of panel $\mathrm{G}$ indicates mitochondrial swelling, and the arrow on the right side of panel $\mathrm{G}$ indicates a lysosome. (H) hRPE cells in the late phase of apoptosis (TEM x10,000, scale bar, $1 \mu \mathrm{m}$ ). The arrow on the left side indicates nuclear membrane shrinkage, and the arrows on the right side indicate damaged, vesicular organelles.

apoptosis, chromatin margination was detected along with a slight increase in the number of mitochondria, mitochondrial swelling and lysosomes (Fig. 2B and C). In middle-to-late apoptosis, the hRPE cells exhibited nuclear membrane shrinkage, mitochondrial swelling (Fig. D-F), as well as a large amount of lysosomes (Fig. 2F). In the late phase of apoptosis, character-
Table III. The effects of curcumin on the cell cycle progression of cultured human retinal pigment epithelial (hRPE) cells after $48 \mathrm{~h}$.

\begin{tabular}{lccr}
\hline $\begin{array}{l}\text { Cell cycle } \\
\text { phase }\end{array}$ & $\begin{array}{c}\text { Control } \\
\text { group }\end{array}$ & $\begin{array}{c}\text { Curcumin-treated } \\
\text { group }\end{array}$ & P-value $^{\mathrm{a}}$ \\
\hline G0/G1 (\%) & $57.17 \pm 1.17$ & $67.73 \pm 1.10$ & $<0.001$ \\
S (\%) & $32.23 \pm 3.47$ & $21.47 \pm 2.03$ & 0.010 \\
G2/M (\%) & $10.64 \pm 3.41$ & $10.83 \pm 1.57$ & 0.935 \\
\hline
\end{tabular}

Data are presented as the means $\pm \mathrm{SD} ; \mathrm{N}=3$ for each group. ${ }^{\text {a Deter- }}$ mined by independent t-test. SD, standard deviation.

istics similar to those of necrotic cells (i.e., rupture of the cell membrane, nuclear membrane shrinkage, injured organelles and cytoplasmic vacuoles) were observed (Fig. 2H).

Effects of curcumin on hRPE cell cycle progression. The cell cycle progression of hRPE cells was then determined following treatment with $15 \mu \mathrm{g} / \mathrm{ml}$ curcumin for $48 \mathrm{~h}$ (Fig. 3). The proportion of hRPE cells in the G0/G1 phase was significantly higher in the curcumin-treated group than in the control group (67.73 vs. 57.17\%; $\mathrm{P}<0.001)$ (Table III). A concomitant decrease in the proportion of curcumin-treated hRPE cells in the $\mathrm{S}$ phase was observed $(\mathrm{P}=0.010)$.

Effects of curcumin on p21 WAFI/CIPI, p53 and PCNA protein expression in hRPE cells. The hRPE cells were treated with $15 \mu \mathrm{g} / \mathrm{ml}$ curcumin for 24,48 and $72 \mathrm{~h}$ after which western blot analysis was undertaken; a representative blot is shown in Fig. 4A. The relative PCNA expression was significantly decreased in the curcumin-treated group as compared to the control group at all time points $(\mathrm{P}<0.05)($ Fig. 4B); however, the relative expression of $\mathrm{p} 21^{\mathrm{WAF} 1 / \mathrm{CIP} 1}$ (Fig. 4C) and p53 (Fig. 4D) was significantly elevated in response to curcumin treatment (all $\mathrm{P}<0.05$ ).

\section{Discussion}

Given the anti-proliferative effects of curcumin for epithelial and endothelial cells, its effects on hRPE cell proliferation were determined in the present study. Similarly, curcumin inhibited hRPE cell proliferation in a dose-dependent manner. The anti-proliferative response by curcumin was mediated in part by increased apoptosis, as well as G0/G1 cell cycle arrest. No induction of necrosis was observed. Furthermore, curcumin increased p21 and p53 protein expression, while decreasing PCNA protein levels.

Curcumin is a diarylheptanoid extracted from the rhizome of Curcuma longa. In vitro studies have demonstrated the antioxidant (35), anti-inflammatory (36), anti-angiogenic (37) and anti-proliferative (38) effects of curcumin in a variety of cells. In the present study, curcumin significantly inhibited the proliferation of hRPE cells in vitro in a dose- and timedependent manner. This is consistent with the cytotoxic effects of curcumin in hRPE cells reported by Hollborn et al (33).

As the WST-1 assay only indirectly reflects cell viability without directly assessing cell proliferation or cell death, 
A

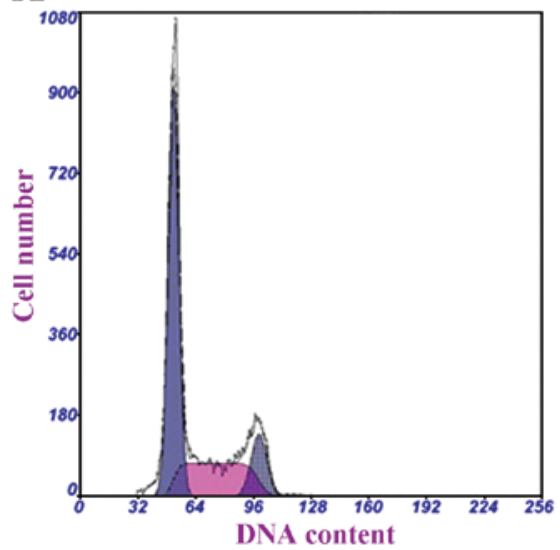

B

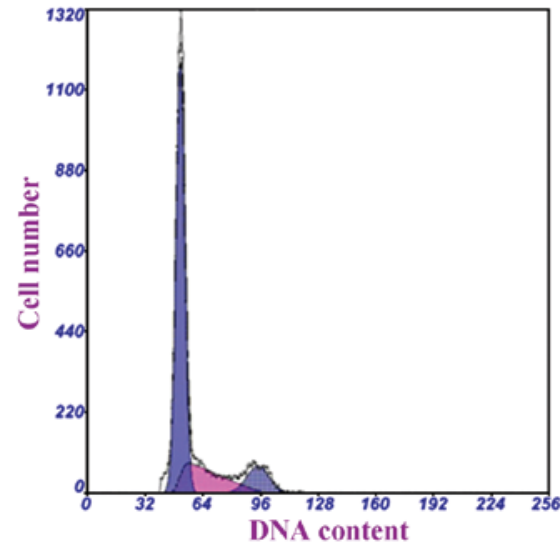

Figure 3. Effect of curcumin on the cell cycle progression of human retinal pigment epithelial (hRPE) cells. Cell cycle analysis of (A) control and (B) curcumintreated hRPE cells ( $15 \mu \mathrm{g} / \mathrm{ml}$ curcumin for $48 \mathrm{~h}$ ). Dark blue color represents the G0/G1 phase, purple represents the $\mathrm{S}$ phase and light blue represents the G2/M phase.

A

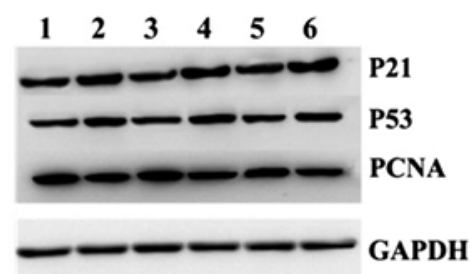

C

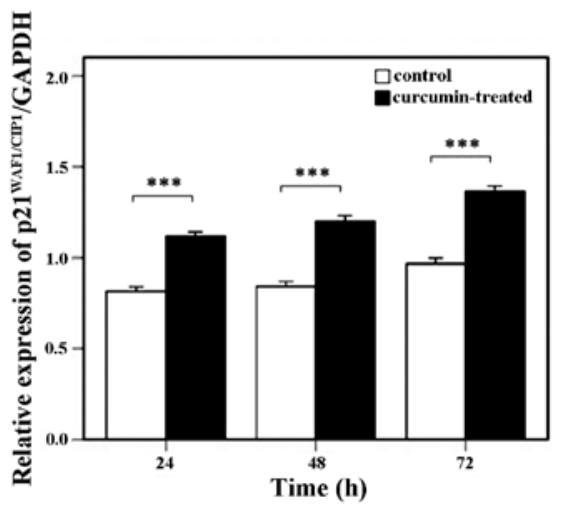

B 플

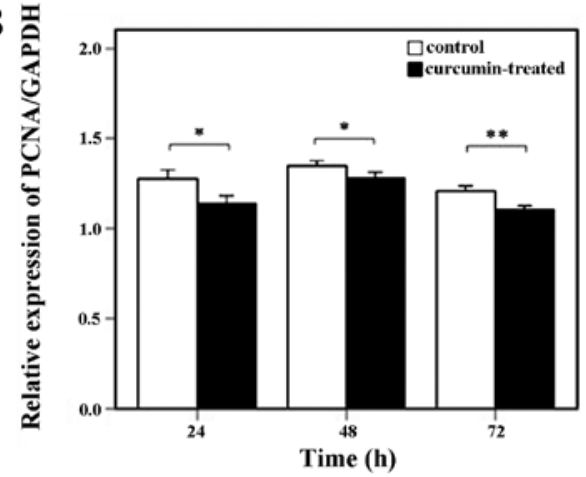

D

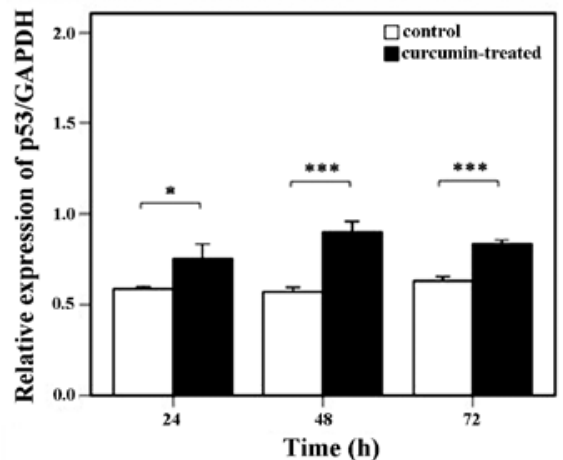

Figure 4. Effects of curcumin on cell cycle-related protein levels. (A) A representative western blot is shown. Lane 1, control at 24 h; lane 2, curcumin treatment for $24 \mathrm{~h}$; lane 3 , control at $48 \mathrm{~h}$; lane 4 , curcumin treatment for $48 \mathrm{~h}$; lane 5 , control at $72 \mathrm{~h}$; and lane 6 , curcumin treatment for $72 \mathrm{~h}$. The relative protein expression of (B) proliferating cell nuclear antigen (PCNA), (C) p2 $1^{\mathrm{WAF} 1 / \mathrm{CIP} 1}$ and (D) $\mathrm{p} 53$ was determined in cultured hRPE cells. Data represent the means \pm standard deviation (SD) of 3 independent experiments for each time point. $* \mathrm{P}<0.05,{ }^{* *} \mathrm{P}<0.01$ and ${ }^{* * * *} \mathrm{P}<0.001$ : significantly different from the control group.

we also assessed the effects of curcumin on apoptosis and necrosis. Although no significant induction of necrosis was observed, treatment with $15 \mu \mathrm{g} / \mathrm{ml}$ curcumin for $48 \mathrm{~h}$ significantly increased the apoptotic rate, which was confirmed by transmission electron microscopy that detected ultrastructural changes consistent with the early and middle-to-late phases of apoptosis. Hollborn et al (33) reported increased hRPE cell necrosis in response to $>10 \mu \mathrm{M}$ curcumin. Differences in the concentration of curcumin used ( $>10 \mu \mathrm{M}$ vs. $15 \mu \mathrm{g} / \mathrm{ml})$, as well as the duration of culture ( 6 and 24 vs. 48 h) may account for the discrepant results with respect to necrosis.

In the present study, curcumin increased the expression of p53, which plays a role in the mitochondrial apoptotic pathway, as well as the expression of its downstream factor, p21 ${ }^{\mathrm{WAF} 1 / \mathrm{CIP} 1}$. This result is consistent with that of a previous study that reported the curcumin-induced apoptosis of retinal vascular endothelial cells (39). In hRPE cells and ARPE19 cells, curcumin has been shown to induce apoptosis through the mitochondrial apoptotic 
pathway (40). These results suggest that curcumin increases mitochondrial outer membrane permeability (MOMP), leading to the release of $\mathrm{p53}$, which in turn elevates MOMP and thereby initiates apoptosis. Given the importance of the p53 pathway and its negative regulator, murine double minute 2 (MDM2), in PVR pathogenesis (41), further studies are required to assess this possibility in detail. Furthermore, curcumin-induced p53 and $\mathrm{p} 21^{\mathrm{WAF} 1 / \mathrm{CIP} 1}$ expression was detected at the same time point, suggesting that $\mathrm{p} 53$ initiates the expression of $\mathrm{p} 21^{\mathrm{WAF} 1 / \mathrm{CIP} 1}$. In a previous study, in hRPE cells treated with $\mathrm{H}_{2} \mathrm{O}_{2}$ for $5 \mathrm{~min}$, an increased $\mathrm{p} 21^{\mathrm{WAF} 1 / \mathrm{CIP} 1}$ expression ensued that of p53 (42). Therefore, we hypothesized that treatment with curcumin may induce the release of p53 from the mitochondria at extremely early time points; however, prolonged curcumin treatment may induce the synthesis of $\mathrm{p} 53$ and $\mathrm{p} 21^{\mathrm{WAF} 1 / \mathrm{CIP} 1}$. As p53 suppresses VEGF, a growth factor relevant to PVR pathogenesis (17) and negatively regulated by curcumin (33), further studies are required to assess the expression of additional p53 downstream factors in response to curcumin, apart from $\mathrm{p} 53$.

In addition to inducing apoptosis, both p53 and p $21^{\text {WAF1/CIP1 }}$ mediate cell cycle arrest. p53 arrests cells in the G1 phase to impair DNA repair or induce apoptosis, and $\mathrm{p} 21^{\mathrm{WAF} 1 / \mathrm{CIP} 1}$ interacts with cyclin-dependent kinase (CDK)2 to arrest cells in the G1 phase, inhibiting DNA replication and mitosis (43-45). Adenovirus-mediated $\mathrm{p} 21^{\mathrm{WAF} 1 / \mathrm{CIP} 1}$ overexpression in retinal vascular endothelial cells inhibits their proliferation and tube formation (46). In the present study, curcumin induced G0/G1 phase arrest in the hRPE cells, which is consistent with that observed in human umbilical vein endothelial cells (HUVECs) (47). Moreover, the proportion of hRPE cells in the $S$ phase was reduced with curcumin treatment, while the number of cells in the G2/M phase remained unaltered. These results were confirmed by evaluating the expression of PCNA, an important marker of cell proliferation involved in DNA synthesis, repair, regulation of the cell cycle, chromosomal rearrangement and DNA methylation. As a co-factor of DNA polymerase $\delta$, PCNA participates in DNA synthesis and replication and regulates entry into the $\mathrm{S}$ phase; its expression is increased in the G1 phase, peaking in the S phase $(48,49)$. In the present study, PCNA levels decreased in the hRPE cells treated with curcumin. This downregulation may be attributed to its increased interaction with $\mathrm{p} 21^{\mathrm{WAF} 1 / \mathrm{CIP} 1}$, which inhibits CDK activity, blocks retinoblastoma protein $(\mathrm{Rb})$ phosphorylation and arrests cells before the $\mathrm{S}$ phase (50). Further studies are required to assess the mechanisms and factors through which curcumin inhibits cell cycle progression in greater detail, including assessing Krüppel-like factor 5 (KLF5), an inhibitor of aberrant cell cycle progression in epithelial cells which functions in part through the regulation of $\mathrm{p} 21^{\mathrm{WAF} 1 / \mathrm{CIP} 1}(51)$.

In addition to hRPE cell proliferation, hyperplastic fibrous tissues of PVR contain ECM components, including collagen I and sometimes collagen II (14). Further studies are required to determine the effects of curcumin on ECM components in PVR.

In conclusion, taken together, our data demonstrate that curcumin effectively inhibits the proliferation of primary hRPE cells in a time- and dose-dependent manner. The cytotoxic effects of curcumin are attributed to reduced cell cycle progression and the induction of apoptosis, which may be related to the p53 and $\mathrm{p} 21^{\mathrm{WAF} 1 / \mathrm{CIP} 1}$ upregulation and the decrease in PCNA expression. We hypothesize that the p53 signaling pathway is involved in the anti-proliferative effects of curcumin on hRPE cells. Further in vivo studies are required to fully explore the therapeutic potential of curcumin for PVR.

\section{References}

1. Rizzolo LJ, Peng S, Luo Y and Xiao W: Integration of tight junctions and claudins with the barrier functions of the retinal pigment epithelium. Prog Retin Eye Res 30: 296-323, 2011.

2. Sparrow JR, Hicks D and Hamel CP: The retinal pigment epithelium in health and disease. Curr Mol Med 10: 802-823, 2010.

3. He S, Chen Y, Khankan R, et al: Connective tissue growth factor as a mediator of intraocular fibrosis. Invest Ophthalmol Vis Sci 49: 4078-4088, 2008.

4. Kaczmarek R and Misiuk-Hojlo M: Patomechanisms in proliferative vitreoretinopathy. Klin Oczna 113: 64-67, 2011.

5. Lei H, Rhéaume MA and Kazlauskas A: Recent developments in our understanding of how platelet-derived growth factor (PDGF) and its receptors contribute to proliferative vitreoretinopathy. Exp Eye Res 90: 376-381, 2010.

6. Lei H, Rhéaume MA, Velez G, Mukai S and Kazlauskas A: Expression of PDGFRalpha is a determinant of the PVR potential of ARPE19 cells. Invest Ophthalmol Vis Sci 52: 5016-5021, 2011.

7. Umazume K, Barak Y, McDonald K, Liu L, Kaplan HJ and Tamiya S: Proliferative vitreoretinopathy in the Swine-a new model. Invest Ophthalmol Vis Sci 53: 4910-4916, 2012.

8. Asaria RH and Charteris DG: Proliferative vitreoretinopathy: developments in pathogenesis and treatment. Compr Ophthalmol Update 7: 179-185, 2006.

9. Leiderman YI and Miller JW: Proliferative vitreoretinopathy: pathobiology and therapeutic targets. Semin Ophthalmol 24: 62-69, 2009.

10. Sebag J: Shaken not stirred. Ophthalmology 108: 1177-1178, 2001.

11. Kim IK and Arroyo JG: Mechanisms in proliferative vitreoretinopathy. Ophthalmol Clin North Am 15: 81-86, 2002.

12. Wickham L and Charteris DG: Glial cell changes of the human retina in proliferative vitreoretinopathy. Dev Ophthalmol 44: 37-45, 2009.

13. Bastiaans J, van Meurs JC, van Holten-Neelen C, et al: Factor $\mathrm{Xa}$ and thrombin stimulate proinflammatory and profibrotic mediator production by retinal pigment epithelial cells: a role in vitreoretinal disorders? Graefes Arch Clin Exp Ophthalmol 251: 1723-1733, 2013.

14. Feist RM Jr, King JL, Morris R, Witherspoon CD and Guidry C: Myofibroblast and extracellular matrix origins in proliferative vitreoretinopathy. Graefes Arch Clin Exp Ophthalmol 252: 347-357, 2014.

15. Halper J and Kjaer M: Basic components of connective tissues and extracellular matrix: elastin, fibrillin, fibulins, fibrinogen, fibronectin, laminin, tenascins and thrombospondins. Adv Exp Med Biol 802: 31-47, 2014.

16. Zhu W, Wu Y, Cui C, Zhao HM, Ba J, Chen $\mathrm{H}$ and $\mathrm{Yu} \mathrm{J}$ : Expression of IGFBP6 in proliferative vitreoretinopathy rat models and its effects on retinal pigment epithelial-J cells. Mol Med Rep 9: 33-38, 2014.

17. Azzolini C, Pagani IS, Pirrone C, et al: Expression of VEGF-A, Otx homeobox and p53 family genes in proliferative vitreoretinopathy. Mediators Inflamm 2013: 857380, 2013.

18. Hou Q, Tang J, Wang Z, et al: Inhibitory effect of microRNA-34a on retinal pigment epithelial cell proliferation and migration. Invest Ophthalmol Vis Sci 54: 6481-6488, 2013.

19. Qiu S, Jiang Z, Huang Z, Chen X, Qian X, Gao Q and Zheng H: Migration of retinal pigment epithelium cells is regulated by protein kinase Calpha in vitro. Invest Ophthalmol Vis Sci 54: 7082-7090, 2013.

20. Ahmadieh H, Feghhi M, Tabatabaei H, Shoeibi N, Ramezani A and Mohebbi MR: Triamcinolone acetonide in silicone-filled eyes as adjunctive treatment for proliferative vitreoretinopathy: a randomized clinical trial. Ophthalmology 115: 1938-1943, 2008.

21. Cheema RA, Peyman GA, Fang T, Jones A, Lukaris AD and Lim K: Triamcinolone acetonide as an adjuvant in the surgical treatment of retinal detachment with proliferative vitreoretinopathy. Ophthalmic Surg Lasers Imaging 38: 365-370, 2007.

22. Yasukawa T, Kimura H, Dong J, Tabata Y, Miyamoto H, Honda Y and Ogura Y: Effect of tranilast on proliferation, collagen gel contraction, and transforming growth factor beta secretion of retinal pigment epithelial cells and fibroblasts. Ophthalmic Res 34: 206-212, 2002. 
23. Krott R, Lebek J, Grisanti S, Esser P and Heimann K: Antiproliferative Wirkung von Genistein auf kultivierte retinale Pigmentepithelzellen vom Schwein. Ophthalmologica 214: 296-300, 2000 (In German).

24. Koutsandrea CN, Miceli MV, Peyman GA, Farahat HG and Niesman MR: Ciprofloxacin and dexamethasone inhibit the proliferation of human retinal pigment epithelial cells in culture. Curr Eye Res 10: 249-258, 1991.

25. Wu WC, Hu DN, Mehta S and Chang YC: Effects of retinoic acid on retinal pigment epithelium from excised membranes from proliferative vitreoretinopathy. J Ocul Pharmacol Ther 21: 44-54, 2005.

26. Sakamoto T, Hinton DR, Kimura H, Spee C, Gopalakrishna R and Ryan SJ: Vitamin E succinate inhibits proliferation and migration of retinal pigment epithelial cells in vitro: therapeutic implication for proliferative vitreoretinopathy. Graefes Arch Clin Exp Ophthalmol 234: 186-192, 1996.

27. Handa JT, Murad S and Jaffe GJ: Inhibition of cultured human RPE cell proliferation and lysyl hydroxylase activity by hydroxy derivatives of minoxidil. Invest Ophthalmol Vis Sci 35: 463-469, 1994.

28. Gao Q and Ge J: The inhibition of $\mathrm{Ca}^{2+}$ influx induced by hypericin in cultured human retinal pigment epithelial cells analyzed by confocal imaging. Ophthalmic Res 37: 128-135, 2005 .

29. Yoo JS, Sakamoto T, Spee C, et al: cis-Hydroxyproline inhibits proliferation, collagen synthesis, attachment, and migration of cultured bovine retinal pigment epithelial cells. Invest Ophthalmol Vis Sci 38: 520-528, 1997.

30. Schmidt JF and Loeffler KU: Toxicity and antiproliferative effect of aclacinomycin A on RPE cells in vitro. Curr Eye Res 15: 1112-1116, 1996

31. Wang YS, Hui YN and Wiedemann P: Role of apoptosis in the cytotoxic effect mediated by daunorubicin in cultured human retinal pigment epithelial cells. J Ocul Pharmacol Ther 18 : 377-387, 2002.

32. Steinhorst UH, Chen EP, Machemer R and Hatchell DL: $\mathrm{N}, \mathrm{N}$-dimethyladriamycin for treatment of experimental proliferative vitreoretinopathy: efficacy and toxicity on the rabbit retina. Exp Eye Res 56: 489-495, 1993.

33. Hollborn M, Chen R, Wiedemann P, Reichenbach A, Bringmann A and Kohen L: Cytotoxic effects of curcumin in human retinal pigment epithelial cells. PLoS One 8: e59603, 2013.

34. Woo JM, Shin DY, Lee SJ, et al: Curcumin protects retinal pigment epithelial cells against oxidative stress via induction of heme oxygenase- 1 expression and reduction of reactive oxygen. Mol Vis 18: 901-908, 2012.

35. Rong S, Zhao Y, Bao W, et al: Curcumin prevents chronic alcoholinduced liver disease involving decreasing ROS generation and enhancing antioxidative capacity. Phytomedicine 19: 545-550, 2012.

36. Katsori AM, Chatzopoulou M, Dimas K, Kontogiorgis C, Patsilinakos A, Trangas T and Hadjipavlou-Litina D: Curcumin analogues as possible anti-proliferative and anti-inflammatory agents. Eur J Med Chem 46: 2722-2735, 2011.

37. Mohan R, Sivak J, Ashton P, et al: Curcuminoids inhibit the angiogenic response stimulated by fibroblast growth factor- 2 , including expression of matrix metalloproteinase gelatinase B. J Biol Chem 275: 10405-10412, 2000.
38. Abusnina A, Keravis T, Yougbare I, Bronner C and Lugnier C: Anti-proliferative effect of curcumin on melanoma cells is mediated by PDE1A inhibition that regulates the epigenetic integrator UHRF1. Mol Nutr Food Res 55: 1677-1689, 2011

39. Premanand C, Rema M, Sameer MZ, Sujatha M and Balasubramanyam M: Effect of curcumin on proliferation of human retinal endothelial cells under in vitro conditions. Invest Ophthalmol Vis Sci 47: 2179-2184, 2006.

40. Alex AF, Spitznas M, Tittel AP, Kurts C and Eter N: Inhibitory effect of epigallocatechin gallate (EGCG), resveratrol, and curcumin on proliferation of human retinal pigment epithelial cells in vitro. Curr Eye Res 35: 1021-1033, 2010.

41. Pastor-Idoate S, Rodríguez-Hernandez I, Rojas J, et al: The T309G MDM2 gene polymorphism is a novel risk factor for proliferative vitreoretinopathy. PLoS One 8: e82283, 2013.

42. Jin GF, Hurst JS and Godley BF: Hydrogen peroxide stimulates apoptosis in cultured human retinal pigment epithelial cells. Curr Eye Res 22: 165-173, 2001.

43. Mahyar-Roemer M and Roemer K: p21 Waf1/Cip1 can protect human colon carcinoma cells against p53-dependent and p53-independent apoptosis induced by natural chemopreventive and therapeutic agents. Oncogene 20: 3387-3398, 2001.

44. Tian H, Wittmack EK and Jorgensen TJ: p21 WAF1/CIP1 antisense therapy radiosensitizes human colon cancer by converting growth arrest to apoptosis. Cancer Res 60: 679-684, 2000.

45. Xu GW, Nutt CL, Zlatescu MC, Keeney M, Chin-Yee I and Cairncross JG: Inactivation of p53 sensitizes U87MG glioma cells to 1,3-bis(2-chloroethyl)-1-nitrosourea. Cancer Res 61: 4155-4159, 2001

46. Han J, Yuan Z and Yan H: Inhibitory effect of adenoviral vectormediated delivery of $\mathrm{p} 21^{\mathrm{WAF} / \mathrm{CIP} 1}$ on retinal vascular endothelial cell proliferation and tube formation in cultured Rhesus monkey cells (RF/6A). Curr Eye Res 38: 670-673, 2013.

47. Wei SC, Lin YS, Tsao PN, Wu-Tsai JJ, Wu CH and Wong JM: Comparison of the anti-proliferation and apoptosis-induction activities of sulindac, celecoxib, curcumin, and nifedipine in mismatch repair-deficient cell lines. J Formos Med Assoc 103: 599-606, 2004.

48. Kirchmaier AL: Ub-family modifications at the replication fork: Regulating PCNA-interacting components. FEBS Lett 585 2920-2928, 2011

49. Strzalka W and Ziemienowicz A: Proliferating cell nuclear antigen (PCNA): a key factor in DNA replication and cell cycle regulation. Ann Bot 107: 1127-1140, 2011

50. Cazzalini O, Perucca P, Riva F, et al: p21CDKN1A does not interfere with loading of PCNA at DNA replication sites, but inhibits subsequent binding of DNA polymerase delta at the G1/S phase transition. Cell Cycle 2: 596-603, 2003.

51. Yang Y, Tarapore RS, Jarmel MH, Tetreault MP and Katz JP: p53 mutation alters the effect of the esophageal tumor suppressor KLF5 on keratinocyte proliferation. Cell Cycle 11: 4033-4039, 2012. 